\title{
Scarabaeinae (Coleoptera: Scarabaeidae) of a rupestrian field at Cafuringa, Distrito Federal, Brazil: commented list of species
}

\author{
Rafael Vieira Nunes ${ }^{1,4}$, Marina Regina Frizzas ${ }^{2}$ \& Fernando Zagury Vaz-de-Mello \\ ${ }^{1}$ Programa de Pós-graduação em Ecologia e Conservação da Biodiversidade, Instituto de Biociências, \\ Universidade Federal de Mato Grosso - UFMT, Av. Fernando Correia da Costa, s/n, Coxipó, \\ CEP 78060-900, Cuiabá, MT, Brasil \\ ${ }^{2}$ Departamento de Zoologia, Instituto de Ciências Biológicas, Universidade de Brasília - UnB, Campus \\ Universitário Darcy Ribeiro, Asa Norte, CEP 70910-900, Brasília, DF, Brasil. http://vsites.unb.br/ib/zoo \\ ${ }^{3}$ Departamento de Biologia e Zoologia, Instituto de Biociências, Universidade Federal de Mato Grosso- \\ UFMT, Av. Fernando Correia da Costa, s/n, Coxipó, CEP 78060-900, Cuiabá, MT, Brasil \\ ${ }^{4}$ Corresponding author: Rafael Vieira Nunes,e-mail: rafavnunes@gmail.com
}

NUNES, R.V., FRIZZAS, M.R. \& VAZ-DE-MELLO, F.Z. Scarabaeinae (Coleoptera: Scarabaeidae) of a rupestrian field at Cafuringa, Distrito Federal, Brazil: commented list of species. Biota Neotrop. 12(4): http://www.biotaneotropica.org.br/v12n4/en/abstract?article+bn02912042012

\begin{abstract}
Our aim was to characterize the Scarabaeinae fauna from a rupestrian field formation at APA de Cafuringa, DF, Brazil. We made seven samples between 2007 and 2009 using baited pitfall traps. We collected 602 individuals belonging to 27 species and 13 genera, of which 17 were identified at species level. The majority of species caught has wide geographical distribution in Brazil and South America and do not seem to be specialized in 'campo rupestre' formation. Two species, Canthidium marseuli and Canthon lamproderes have restricted geographical distribution, being present in the central Brazilian highlands. C. marseuli and C. lamproderes are probably restricted to rupestrian fields since they have been registered only for this formation in Brazil, which indicates that these species need attention in relation to the conservation of theirs populations and habitats.

Keywords: altitude, cambisoils, Canthidium marseuli, Canthon lamproderes.
\end{abstract}

NUNES, R.V., FRIZZAS, M.R. \& VAZ-DE-MELLO, F.Z. Scarabaeinae (Coleoptera: Scarabaeidae) de um campo rupestre na Área de Proteção Ambiental de Cafuringa, Distrito Federal, Brasil: lista comentada de espécies e distribuição geográfica. Biota Neotrop. 12(4): http://www.biotaneotropica.org.br/v12n4/pt/ abstract?article+bn02912042012

Resumo: Nosso objetivo foi caracterizar a fauna de Scarabaeinae de um campo rupestre na APA de Cafuringa, DF, Brasil. Nós realizamos sete amostragens entre os anos de 2007 e 2009 utilizando armadilhas tipo pitfall com isca. Coletamos 602 indivíduos pertencentes a 27 espécies, 13 gêneros, das quais 17 delas estão identificadas até nível específico. A maioria das espécies coletadas apresenta ampla distribuição geográfica no Brasil e América do Sul e não parece ser especializada em formações do tipo campo rupestre. Duas espécies, Canthidium marseuli e Canthon lamproderes tem distribuição geográfica restrita aos campos de altitude do centro-sul do Brasil. C. marseuli e C. lamproderes são provavelmente habitantes restritas dos campos rupestres, visto que foram registradas apenas nesse tipo de formação no Brasil, o que indica que essas espécies necessitam de atenção em relação à conservação das suas populações e dos seus habitats.

Palavras-chave: altitude, cambissolos, Canthidium marseuli, Canthon lamproderes. 


\section{Introduction}

Rupestrian fields can be found at Brazilian Cerrado and Caatinga usually occurring above 900 meters on mountains associated with preCambrian stones remolded by tectonic movements since Paleocene (Vasconcelos 2011). This formation is mainly associated to quartzite, silicate and iron allurements (Vasconcelos 2011). This physiognomy has a disjunct distribution since Chapada Diamantina, in the state of Bahia, to mountain formations in the south of the state of Minas Gerais (Rapini et al. 2008) also occurring in the states of Goiás and Distrito Federal (Reatto et al. 2002, Vasconcelos 2011). Two features make the rupestrian fields a peculiar formation. First, from biogeographical and historical point of view, rupestrian fields can be understood as islands or archipelagos surrounded by a matrix of low altitude areas. In long term, this isolation can favor speciation processes and thus, the occurrence of an exclusive highland fauna and flora (Safford 1999, Alves et al. 2007, Azevedo et al. 2008, Vasconcelos 2011) Secondly, soil features can be, for some taxa, a determinant factor on rupestrian field ecology, modeling the physiognomy and influencing the local biota (Eiten 1972).

Dung beetles of subfamily Scarabaeinae constitute a taxonomic group which distribution and ecology might be affected by those rupestrian field features. This subfamily is worldwide distributed and currently includes about 7000 described species and, securely, more than 1500 at South America (Hanski \& Cambefort 1991, Vazde-Mello 2000, Davis \& Scholtz 2001). Dung beetles have a strong dependence on soil characteristics since many species have the habit to bury feces to build their nests (Halffter \& Matthews 1966). Besides, Scarabaeinae clade has a Mesozoic origin, about 200 million years ago (Davis et al. 2002), which, associated with the also ancient origin of rupestrian field (30 million years ago, median tertiary according to Safford (1999)), enable the existence of patterns of endemism on mountain tops (Safford 1999).

A higher knowledge about Scarabaeinae inhabiting Brazilian rupestrian fields will help, a posteriori, to understand more about biogeographical and historical aspects of Brazilian Dung beetles - a theme that has been neglected due the low number of publication in this area. Thus, our aim was to characterize taxonomically the Scarabaeinae fauna at a rupestrian field at Cafuringa, DF, Brazil.

\section{Materials and Methods}

\section{Study site}

The study was conducted in a rupestrian field area located near road DF 170, at Área de Proteção Ambiental de Cafuringa (APA de Cafuringa), Distrito Federal Brazil ( $15^{\circ} 32^{\prime} \mathrm{S}$ and $42^{\circ} 02^{\prime} \mathrm{W}, 1200 \mathrm{~m}$ over sea level) (Figure 1). APA de Cafuringa has 49.000 ha, it is located in northwest of Distrito Federal and constitutes an important area for conservation of rupestrian fields and dry forests in central Brazil. According to Köppen's climatic classification, the climate in this site can be classified as tropical of altitude ( $\mathrm{Cwb})$, which is characterized by two defined stations: one dry station, with lower absolute temperature and precipitation, when occurs between May and September and a humid station with higher absolute temperature and precipitation, when occurs between October and March (Companhia... 1984). Cwb climate types are similar to tropical humid type (Cwa), which also occurs in Distrito Federal. However, Cwb climate type has lower mean temperature and lower mean precipitation than Cwa. Geologically, the study site is characterized by the presence of haplic cambisols with mountainous relief, formation that occurs in $3.1 \%$ of Brazilian Cerrado soils (Reatto et al. 2002).

\section{Data sampling}

During December 2007 to April 2008 we made six mensal samples in three sites (A, B, C), each one with one hectare (Figure 1). In each site we installed nine pitfall traps, three baited with rotten banana, three baited with human feces and three baited rotten bovine liver. The traps remained for 48 hours in the study site. Each sampled site consisted of three lines, $50 \mathrm{~m}$ apart, with three pitfalls spaced

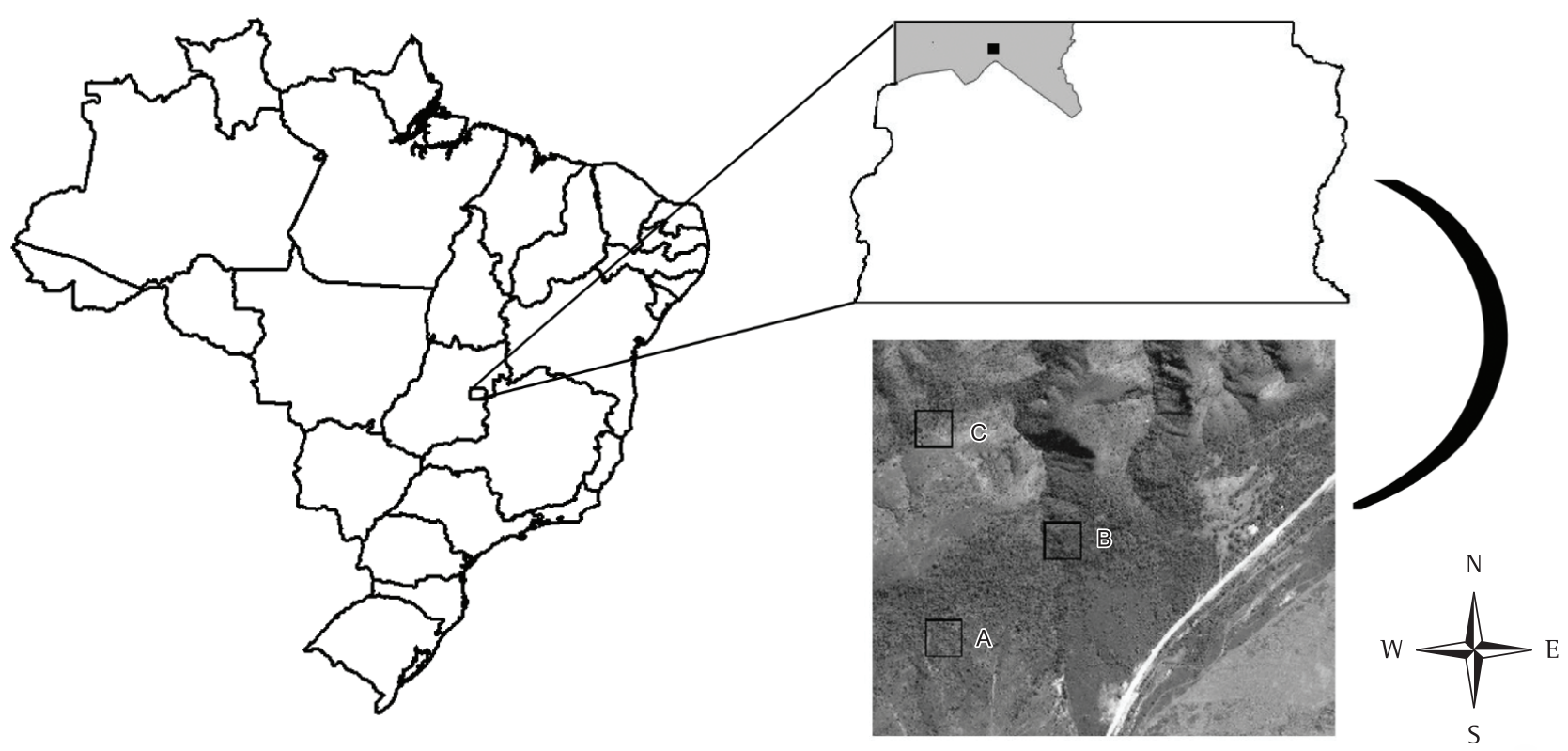

Figure 1. Localization of APA de Cafuringa (grey) in Distrito Federal and Brazil. The black spot on APA de Cafuringa represents the three sampled areas (A, $\mathrm{B}$ and C), showed on the satellite image. Font: Google Earth.

Figura 1. Localização da APA de Cafuringa (cinza) no Distrito Federal e Brasil. O ponto preto marcado na APA de Cafuringa representa as três áreas amostradas (A, B e C), mostradas na imagem de satélite. Fonte: Google Earth. 
$50 \mathrm{~m}$ totaling nine pitfalls per month in each area. Additionally, on December 2009, we installed five pitfalls baited with human feces in site "A" (Figure 1).

Dung beetles were identified using taxonomic key for Neotropical Scarabaeinae genera (Vaz-de-Mello et al. 2011), consulting published taxonomic literature and consulting the Entomology Section of Zoological Collection of Universidade Federal de Mato Grosso - CEMT. The identifications were conducted by the third author. The collected beetles are vouchered in CEMT.

Data concerning geographical distribution of species were obtained in published literature and consulting records in CEMT.

\section{Results}

A total of 602 beetles from 27 species and 13 genera were collected (Table 1). Canthidium barbacenicum was the most abundant species in samples $(\mathrm{n}=179)$ followed by Dichotomius aff. glaucus $(\mathrm{n}=85)$. Agamopus viridis, Ontherus carinicollis and Trichillum externepunctatum were collected only in the additional sample done in December 2009. Except for Dendropaemon sp., which was collected only in pitfalls baited with rotten banana, all species were collected using human feces bait or rotten bovine liver bait (Table 1).
In rupestrian field of APA de Cafuringa, 15 species have wide geographic distribution while two species have geographic distribution restricted to altitude areas or rupestrian fields (Table 1). For ten species, distribution could not be inferred since they were not identified until species level.

\section{Discussion}

Between the species that have a wide geographic distribution, many of them are easily found in Brazilian exotic and natural pastures and are usually associated with human or bovine dung (Köller et al. 2007, Louzada \& Carvalho e Silva 2009) case of Agamopus viridis, two species of Ateuchus, Canthidium barbacenicum, Canthon pilluliforme and Dichotomius bos. Canthon histrio, Trichillum externepunctatum, Oxysternon palemo and Dichotomius nisus, also associated with human and bovine dung, are very common in altered environments and the last two occurs also in urban environments in the city of Brasília, DF. Canthidium decoratum was collected in the rupestrian fields and Cerrado formations in the states of São Paulo, Minas Gerais, Bahia and Mato Grosso (Pessôa \& Lâne 1944, CEMT Records) while Dichotomius crinicollis was recorded in "Brejo de Altitude" in the state of Pernambuco (Silva et al. 2007) and in open

Table 1. Identification, author, year, capture method, $\mathrm{A}(\mathrm{F})$ abundance on traps baited with human feces, $\mathrm{A}(\mathrm{B})$ abundance on traps baited with banana, $\mathrm{A}(\mathrm{BL})$ abundance on traps baited with bovine liver and geographic distribution of Scarabaeinae species collected in campo rupestre at APA de Cafuringa between years 2007 and 2009. *species caught only in 2009. (PF) Pitfall baited with human feces, (PB) pitfall baited with rotten banana, (PFB) pitfall baited with rotten bovine liver. (AM) Wide distribution in Brazil and South America, (RE) Restricted distribution to rupestrian and altitudinal fields in Central Brazil.

Tabela 1. Identificação, autor, ano, método de coleta, A(F) abundância em armadilhas iscadas com fezes humanas, A(B) abundância em armadilhas iscadas com banana, $\mathrm{A}(\mathrm{BL})$ abundância em armadilhas iscadas com fígado bovino e distribuição geográfica das espécies de Scarabaeinae de campo rupestre na APA de Cafuringa entre os anos de 2007 e 2009. * espécies coletadas apenas em 2009. (PF) pitfall iscado com fezes humanas, (PB) pitfall iscado com banana em decomposição, (PFB) pitfall iscado com fígado bovino em decomposição. (AM) Ampla distribuição no Brasil e América do Sul, (RE) Distribuição restrita a campos de altitude e rupestres do Brasil central.

\begin{tabular}{|c|c|c|c|c|c|}
\hline $\begin{array}{r}\text { Species } \\
\end{array}$ & Method & $\mathbf{A}(\mathbf{F})$ & A (B) & $\mathbf{A}(\mathbf{B L})$ & Distribution \\
\hline Agamopus viridis Boucomont, 1928* & $\mathrm{PF}$ & 19 & - & - & $\mathrm{AM}$ \\
\hline Ateuchus striatulus (Preudhomme de Borre, 1886) & $\mathrm{PF}$ & 1 & - & - & AM \\
\hline Ateuchus vividus (Germar, 1823) & $\mathrm{PF}$ & 85 & - & - & AM \\
\hline Canthidium barbacenicum Preudhomme de Borre, 1886 & $\mathrm{PF}, \mathrm{PB}, \mathrm{PFB}$ & 173 & 2 & 4 & $\mathrm{AM}$ \\
\hline Canthidium decoratum (Perty, 1830) & $\mathrm{PF}$ & 8 & - & - & AM \\
\hline Canthidium marseuli Harold, 1867 & PF, PFB & 1 & - & 1 & $\mathrm{RE}$ \\
\hline Canthidium sp.1 & $\mathrm{PF}, \mathrm{PFB}$ & 22 & - & 1 & - \\
\hline Canthidium sp.2 & $\mathrm{PF}, \mathrm{PFB}$ & 17 & - & - & - \\
\hline Canthon histrio (Lepelletier de Saint Fargeau \& Audinet-Serville, 1828) & $\mathrm{PF}$ & 4 & - & - & AM \\
\hline Canthon lamproderes (Redtenbacher, 1867) & $\mathrm{PF}, \mathrm{PFB}$ & 41 & - & 3 & $\mathrm{RE}$ \\
\hline Canthon aff. pilluliformis Blanchard, 1845 & PF, PFB & 26 & - & 1 & - \\
\hline Canthon sp.1 & $\mathrm{PF}$ & 2 & - & - & - \\
\hline Canthon sp.2 & $\mathrm{PF}$ & 1 & - & - & - \\
\hline Deltochilum sp.1 & $\mathrm{PF}, \mathrm{PB}, \mathrm{PFB}$ & 4 & 4 & 2 & - \\
\hline Dendropaemon sp. & $\mathrm{PB}$ & - & 1 & - & - \\
\hline Dichotomius bos (Blanchard, 1845) & $\mathrm{PF}$ & 18 & - & - & $\mathrm{AM}$ \\
\hline Dichotomius crinicollis (Germar, 1824) & $\mathrm{PF}, \mathrm{PFB}$ & 5 & - & 1 & $\mathrm{AM}$ \\
\hline Dichotomius nisus (Olivier, 1789) & $\mathrm{PF}$ & 2 & - & - & AM \\
\hline Dichotomius aff. glaucus (Harold, 1869) & $\mathrm{PF}, \mathrm{PFB}, \mathrm{PB}$ & 83 & 1 & 7 & - \\
\hline Ontherus carinicollis Luederwaldt, 1931* & $\mathrm{PF}$ & 5 & - & - & $\mathrm{AM}$ \\
\hline Onthophagus sp.1 & $\mathrm{PF}$ & 8 & - & - & - \\
\hline Onthophagus sp.2 & $\mathrm{PF}$ & 6 & - & - & - \\
\hline Onthophagus sp.3 & $\mathrm{PF}$ & 3 & - & - & - \\
\hline Oxysternon palemo Castelnau 1840 & $\mathrm{PF}, \mathrm{PFB}, \mathrm{PB}$ & 11 & 2 & 1 & $\mathrm{AM}$ \\
\hline Phanaeus palaeno Blanchard, 1845 & $\mathrm{PF}$ & 5 & - & - & AM \\
\hline Trichillum adjunctum Martínez, 1967 & $\mathrm{PF}$ & 3 & - & - & $\mathrm{AM}$ \\
\hline Trichillum externepunctatum Preudhomme de Borre, $1886^{*}$ & $\mathrm{PF}$ & 18 & - & - & AM \\
\hline
\end{tabular}


areas and gallery forests at Distrito Federal and Minas Gerais (CEMT Records). Phanaeus paleno is distributed along all Brazilian Cerrado (Edmonds 1994).

It is probable that these species are not selective in terms of habitat, what would be a competitive advantage for colonization and establishment in rupestrian field. Rupestrian field soil might limit the occurrence of common species in Cerrado. The variation on humidity as well the type and composition of soils are strong factors that might affect Scarabaeinae community structure (Doube 1983, Davis 2002) and capacity of species in building nests (Barkhouse \& Ridssil-Smith 1986).

In this study, two species have restricted geographical distribution: Canthidium marseuli and Canthon lamproderes. Besides the records provided here, $C$. marseuli is reported only in rupestrian fields in south of state of Minas Gerais (Almeida \& Louzada 2009) while Canthon lamproderes was registered also in rupestrian fields at Serra da Canastra and Serra do Espinhaço, both on south of the state of Minas Gerais (CEMT Records)

Altitude can be an important biogeographical component that influences the composition of Scarabaeinae fauna in a given region (Lobo \& Halffter 2000). As in other taxa (Safford 1999, Alves et al. 2007, Azevedo et al. 2008, Vasconcelos 2011) it may also be determinant for Scarabaeinae in Central Brazil rupestrian fields. The isolation of these areas does not constitute only a physical barrier that restrains the transition of species; through the years, the historical persistence of rupestrian fields and altitudinal fields may have favoured the co-evolution of rupestrian biotic components (Safford 1999, Vasconcelos 2008, Vasconcelos \& Rodrigues 2010). Since in Distrito Federal rupestrian fields are not much higher than the other environments, the transition of faunal elements between environments is more visible. However is probable that higher and more isolated rupestrian fields have major occurrences of endemic or exclusive species.

As in other studies involving Scarabaeinae community and taxocenosis in Neotropical region, the identity of some taxa could not be determined. Between these taxa, there are some genera that need urgent taxonomic revision (Vaz-de-Mello 1999) like Canthon, Canthidium, Deltochilum and Onthophagus. Other genera are already in revision process like Dichotomius and Dendropaemon. Higher knowledge of these genera will allow more detailed studies involving biogeographical patterns on rupestrian fields and others environments in Brazilian Cerrado.

Towards the kind of bait used for Scarabaeinae sampling, human feces caught higher richness and abundances than the other baits, results that agree with other studies in Neotropical region (Milhomem et al. 2003). Despite that, is important to emphasize that the using of other sampling methods can collect Scarabaeinae that have other habits beyond the use of feces (different kinds of baited pitfalls) or that do constant dislocation by flight (flight interception traps).

Taxonomic composition of Scarabaeinae in rupestrian field in APA de Cafuringa seems to be influenced by an ecological component related to soil feature, that acts like a selector due its relations to Scarabaeinae nest construction (Halffter \& Matthews 1966). This fauna is also influenced by a historical aspect, characterized by the presence of species apparently typical of high altitudes in southcentral Brazil. The restriction on geographic distribution and the apparent exclusivity of habitat of Canthidium marseuli and Canthon lamproderes indicate that these species need attention in relation to its populations and habitat, essential criteria used to access the conservation status of species (International... 2010).

\section{Acknowledgements}

RVN thanks to CAPES for concession of Mastership grant. During the period of data sampling, RVN was received scientific initiation grant from Centro Universitário de Brasília - Uniceub. FZVM Financial sources: CNPq (PDJ 151603/2007-3 e PQ 304925/2010-1), FAPEMAT (570847/2008 e 447441/2009).

\section{References}

ALMEIDA, S.P. \& LOUZADA, J.N.C. 2009. Estrutura da comunidade de Scarabaeinae (Scarabaeidae: Coleoptera) em Fitofisionomias do Cerrado e sua Importância para a Conservação. Neotrop. Entomol. 38(1):032-043.

ALVES, R.J.V., CARDIN, L. \& KROPF, M.S. 2007. Angiosperm disjucntion "Campos rupestres - restingas": a re-evaluation. Acta bot. bras. 21(3):675685.

AZEVEDO, A.A., SILVEIRA, F.A., AGUIAR, C.M.L. \& PEREIRA, V.S. 2008. Fauna de abelhas (Hymenoptera, Apoidea) nos campos rupestres da Cadeia do Espinhaço (Minas Gerais e Bahia, Brasil): riqueza de espécies, padrões de distribuição e ameaças para conservação. Megadiversidade 4(1-2):126-157.

BARKHOUSE, J. \& RIDSILL-SMITH, T.J. 1986. Effect of soil misture on brood ball production by Onthophagus binodis Thunberg and Euoniticellus intermedius (Reiche) (Coleoptera: Scarabaeinae). J. Aust. Entomol. Soc. 25:75-78. http://dx.doi.org/10.1111/j.1440-6055.1986. tb01076.x

COMPANHIA DE PLANEJAMENTO DO DISTRITO FEDERAL - CODEPLAN. 1984. Atlas do Distrito Federal. Brasília: Codeplan. v.II.

DAVIS, A.L.V. 2002. Dung beetle diversity in South Africa: influential factors,conservation status, data inadequacies and survey design. Afr. Entomol. 10(1):53-65.

DAVIS, A.L.V. \& SCHOLTZ, C.H. 2001. Historical vs. ecological factors influencing global patterns of scarabaeinae dung beetle diversity. Divers. Distrib. 7:161-174. http://dx.doi.org/10.1111/j.1472-4642.2001.00102.x

DAVIS, A.L.V., SCHOLTZ, C.H. \& PHILIPS, K.T. 2002. Historical biogeography of scarabaeinae dung beetles. J. Biogeogr. 29:1217-1256. http://dx.doi.org/10.1046/j.1365-2699.2002.00776.x

DOUBE, B. 1983. The habitat preference of some bovine dung beetles (Coleoptera: Scarabaeidae) in Hluhluwe Game Reserve, South Africa. Bull. Entomol. Res. 73:357-371. http://dx.doi.org/10.1017/ S0007485300008968

EDMONDS, W.D. 1994. Revision of Phanaeus Macleay, a New World Genus of Scarabaeinae Dung Beetles (Coleoptera: Scarabaeidae, Scarabaeinae). Contr. In Sci. 443:1-105.

EITEN, G. 1972. The cerrado vegetation of Brazil. Bot. Rev. 38:201-341. http://dx.doi.org/10.1007/BF02859158

HALFFTER, G. \& MATTHEWS, E.G. 1966. The natural history of dung beetles of the subfamily Scarabaeinae (Coleoptera: Scarabaeidae). Fol. Entomol Mex. 14(12):1-312.

HANSKI, I. \& CAMBEFORT, Y. 1991. Dung beetle ecology. Princeton University Press, Princeton. $481 \mathrm{p}$.

INTERNATIONAL UNION FOR CONSERVATION OF NATURE - IUCN. 2010. Guidelines for Using the IUCN Red List Categories and Criteria. version 8.1. http://intranet.iucn.org. (last access on $26 / 12 / 2010$ ).

KÖLLER, W.W., GOMES, A., RODRIGUES, S.R. \& GOIOZO, P.F.I. 2007. Scarabaeinae e Aphodiinae coprófagos em pastagens cultivadas em áreas do cerrado sul-matogrossense. Rev. Bras. Zoocienc. 9(1):81-93.

LOBO, J.M. \& HALFFTER, G. 2000. Biogeographical and Ecological Factors Affecting the Altitudinal Variation of Mountainous Communities of Coprophagous Beetles (Coleoptera: Scarabaeoidea): a Comparative Study. Ann. Entomol. Soc. Am. 93(1):115-126. http://dx.doi.org/10.1603/00138746(2000)093[0115:BAEFAT]2.0.CO;2 
LOUZADA, J.N.C. \& CARVALHO E SILVA, P.R. 2009. Utilisation of introduced Brazilian pastures ecosystems by native dung beetles: diversity patterns and resource use. Insect. Conserv. Diver. 2: 45-52. http://dx.doi. org/10.1111/j.1752-4598.2008.00038.x

MILHOMEM, M.S., VAZ-DE-MELLO, F.Z. \& DINIZ, I.R. 2003. Técnicas de coleta de besouros copronecrófagos no Cerrado. Pesq. Agro. Brasil. 38(11):1249-1256.

PESSÔA, S.B. \& LÂNE, F. 1941. Coleópteros necróphagos de interêsse médico-legal. Ensáio monográfico sôbre a família Scarabaeidae de S. Paulo e regiões vizinhas. Arq. Zool . Est. Sao Paulo. 2:389-504.

RAPINI, A., RIBEIRO, P.L., LAMBERT, S. \& PIRANI, J.R. 2008. A flora dos campos rupestres da Cadeia do Espinhaço. Megadiversidade. 4(12):16-24.

REATTO, A., MARTINS, E.S., FARIAS, M.F.R., SILVA, A.V. \& SPERA, S.T. 2002. Levantamento de Reconhecimento de Alta Intensidade dos Solos da Apa de Cafuringa-DF, escala 1:100.000. Embrapa, Planaltina, 45p. Boletim de Pesquisa e Dersenvolvimento, 47.

SAFFORD, H.D. 1999. Brazilian Páramos I. An introduction to the physical environment and vegetation of the campos de altitude. J. Biogeogr. 26:693712. http://dx.doi.org/10.1046/j.1365-2699.1999.00313.x

SILVA, F.A.B., HERNÁNDEZ, M.I.M., IDE, S. \& MOURA, R.C. 2007. Comunidade de escabrabeíneos (Coleoptera, Scarabaeidae) copronecrófagos da região de Brejo Novo, Caruaru, Pernambuco, Brasil. Rev. Bras. Entomol. 51(2):228-233. http://dx.doi.org/10.1590/S008556262007000200014
VASCONCELOS, M.F. 2008. Mountaintop endemism in eastern Brazil: why some bird species from campos rupestres of the Espinhaço Range are not endemic to the Cerrado region. Rev. Bras. Ornit. 16(4):348-362.

VASCONCELOS, M.F. \& RODRIGUES, M. 2010. Patterns of geographic distribution and conservation of the open-habitat avifauna of Southeastern Brazilian Mountaintops (campos rupestres and campos de altitude). Pap. Avulses. Zool. 50(1):1-29.

VASCONCELOS, M.F. 2011. O que são campos rupestres e campos de altitude nos topos de montanha do Leste do Brasil?. Revista Brasil. Bot. 34(2):241-246.

VAZ-DE-MELLO, F.Z. 1999. Scarabaeidae s.str. (Coleoptera, Scarabaeoidea) de um fragmento de floresta amazônica no estado do Acre, Brasil. An. Soc. Entomol. Bras. 28(3):447-453. http://dx.doi.org/10.1590/S030180591999000300009

VAZ-DE-MELLO, F.Z. 2000. Estado de Conhecimento dos Scarabaeidae do Brasil. In Hacia un proyecto CYTED para el inventário y estimación de la diversidad entomológica en Iberoamérica: PRIBES 2000. (F. MartinPiéra, J.J. Morrone, A. Melic, orgs). Sociedad Entomológica Aragonesa, Zaragosa, p.183-195.

VAZ-DE-MELLO, F.Z., EDMONDS, W.D., OCAMPO, F. \& SCHOOLMEESTERS, P. 2011. A multilingual key to the genera and subgenera of the subfamily Scarabaeinae of the New World (Coleoptera: Scarabaeidae). Zootaxa, 2854:1-73. 